\title{
PENGARUH MODEL PEMBELAJARAN INQUIRY TERHADAP HASIL BELAJAR SEPAKBOLA PADA SISWA KELAS VIISMP NEGERI 3 SUKASADA
}

\author{
Oleh \\ Niko Andi Setyo, Wahjoedi, I Made Satyawan \\ Program Studi Pendidikan Jasmani, Kesehatan dan Rekreasi \\ Jurusan Pendidikan Olahraga \\ Fakultas Olahraga dan Kesehatan \\ Universitas Pendidikan Ganesha \\ Singaraja-Indonesia
}

\begin{abstract}
e-mail: nikoandy266@gmail.com, wahjoedi.bali9@gmail.com. Made.satyawan@undiksha.ac.id
\end{abstract}

\begin{abstract}
ABSTRAK
Penelitian ini bertujuan mengetahui pengaruh model pembelajaran Inquiry terhadap hasil belajar passing dan control sepakbola menggunakan kaki bagian dalam. Penelitian ini adalah penelitian eksperimen sungguhan dengan rancangan penelitian the post test only control group design. Subjek penelitian adalah peserta didik kelas VII SMP Negeri 3 Sukasada Tahun Pelajaran 2018/2019 berjumlah 124 orang yang terdistribusi dalam 4 kelas. Teknik sampling yang digunakan adalah cluster random sampling dengan jumlah 60 orang peserta didik. Data hasil belajar dikumpulkan melalui tes unjuk kerja. Analisis data menggunakan Uji-t dengan taraf signifikansi $\alpha=0,05$. Pada kelompok eksperimen diperoleh nilai rata-rata 77,00 dengan standar deviasi 14.36. Sedangkan pada kelompok kontrol diperoleh nilai rata-rata 60,00 dengan standar deviasi 16.50. Data berdistribusi normal dan homogen. Hasil uji-t menunjukkan $0,000<0,05 \quad(p<0,05)$. Berdasarkan analisa data dan pembahasan disimpulkan bahwa model pembelajaran Inquiry berpengaruh sangat signifikan terhadap peningkatan hasil belajar passing dan control sepakbola pada peserta didik kelas VII SMP Negeri 3 Sukasada tahun pelajaran 2018/2019.
\end{abstract}

Kata-kata kunci : Inquiry, passing dan control Sepakbola.

\section{ABSTRACT}

This study aimed to determine the effect of Inquiry learning model on the results of learning passing and control of football using the inner leg. This study was a real experimental design with a post-test only control group design. The research subjects were VII grade students of SMP Negeri 3 Sukasada in 2018/2019 academic year, in which they were 124 people distributed in 4 classes. The sampling technique used was cluster random sampling with a total of 60 students. Data on learning outcomes are collected through performance tests. The data were analyzed by using t-test with a significance level of $\square=0.05$. In the experimental group obtained an average value of 77.00 with a standard deviation of 14.36. While in the control group the average value was 60.00 with a standard deviation of 16.50 . Data was normally distributed and homogeneous. The results of the t-test showed $0,000<0,05(p<0,05)$. Based on the data analysis and discussion it can be concluded that the Inquiry learning model had a very significant effect on improving the learning outcomes of basic football passing and control in class VII students of SMP Negeri 3 Sukasada 2018/2019 academic year.

Keywords: Inquiry, passing and football control. 


\section{A. PENDAHULUAN}

Pendidikan adalah proses pembelajaran dan pemahaman kemampuan induvidu melalui pengajaran, pelatihan, dan penelitian. Salah satunya dengan pendidikan jasmani, olahraga dan kesehatan (PJOK) merupakan proses pendidikan melalui aktivitas jasmani dan olahraga untuk pengembangkan dan meningkatkan serta proses interaksi antar peserta didik guna mencapai tujuan pendidikan. Menurut Trisna (2016:2) PJOK adalah proses pendidikan yang memanfaatkan aktivitas jasmani yang direncanakan secara sistematik bertujuan untuk mengembangkan dan meningkatkan individu secara organik, neuromuskuler, perseptual, pengetahuan, dan emosional, dalam kerangka sistem pendidikan nasional, PJOK perlu adanya suatu pembelajaran yang bervariasi dan berkembang agar proses pembelajaran tidak monoton dan terkesan membosankan oleh karena itu peneliti melakukan observasi disekolah SMP N 3 Sukasada didalam melakukan observasi peneliti menemukan kendala dalam proses pembelajaran yakni hasil praktek nilai ulangan harian passing dan control sepakbola menggunakan kaki bagian dalam yang dimana siswa kelas VII masih dibawah (Ketuntasan Kelulusan Minimal (KKM). Peneliti ingin memberikan pengaruh pada proses pembelajaran yang dapat membantu siswa lebih aktif dan kreatif dalam beraktivitas serta berfikir kritis dan analisis dengan standar penilaian yang berlaku.

Maka solusinya yaitu dengan menerapkan model pembelajaran

\section{B. KAJIAN TEORI}

Penelitian ini dilaksanakan di SMP Negeri 3 Sukasada pada kelas VII C dan VII D tahun pelajaran 2018/2019. Menggunakan penelitian eksperimen sungguhan dengan yang Menyenangkan, Unik, Kreatif, Inovatif, Denotatif, Inspiratif. (MUKIDI) dan siswa mampu perfikir kritis dan analisis dalam proses belajar. Menurut Trisna (2016:203) model pembelajaran inqury suatu pencarian makna yang memasyarakatkan seseorang untuk melakukan sejumlah operasional intelektual untuk menciptakan pengalaman serta siswa dituntun untuk berfikir kritis dan analisis untuk menemukan jawaban sendiri atas sebuah pertanyaan. Peneliti Pemilihan model pembelajaran inquiry didukung dengan hasil penelitian yang sudah pernah dilakukan oleh Agon Ardiansyah (2017) Pengaruh Model Pembelajaran inquiry Terhadap Hasil Belajar Lay Up Pada Materi Bola Basket pada siswa kelas VIII SMP Negeri 2 Singaraja tahun pelajaran 2016/2017 dan Abdul Khamid (2018) Pengaruh Model Pembelajaran Kooperatif Dan Inkuiri Terhadap Hasil Belajar Bola Voli Passing Bawah Pada Siswa Kelas VIII Smp Negeri 2 Mranggen Kabupaten Demak Tahun Ajaran 2016/2017 yang memberikan pengaruh model pembelajaran inkuiri adalah Pre-Test 13.8 dan Post-Test 20.5.

Latar belakang diatas sudah mengambarkan bahwa peneliti akan melakukan penelitian yang berjudul "Pengaruh Model Pembelajaran Inquiry Terhadap Hasil Belajar Passing dan Control Sepakbola pada Siswa Kelas VII SMP Negeri 3 Sukasada Tahun Pelajaran 2018/2019.

Rancangan/desain pada penelitian ini adalah posttest only control group design. pembelajaran adalah suatu proses interaksi antara guru dan peserta didik secara terpogram dalam 
desain intruksional yang berkelanjutan dalam pengembangan dan pengalaman hidup untuk perubahan tingkah laku. maka dari itu PJOK sangat berperan penting untuk memberikan kesempatan pada seseorang dalam aktivitas jasmani, bermain dan olahraga sekaligus membentuk pola hidup sehat. Karena pada dasarnya PJOK berhubungan dengan kesanggupan seseorang untuk menggerakkan anggota badan. Namun bukan hanya menggerakkan anggota badan melainkan juga memerlukan keterampilan sikap dan intelektual. Oleh karena itu, bagi seseorang yang ingin mempelajari keterampilan gerak terlebih dahulu harus memahami dan menguasai prosedur gerakan yang dilakukan disertai konsep cara-cara melakukannya. Di dalam program pengajaran PJOK, setiap bentuk bahan pelajaran keterampilan gerak biasanya memiliki urutan gerak yang harus dilakukan dengan cepat, tepat, luwes, dan lancar.

Sepakbola sejatinya adalah permainan tim, walaupun pemain yang memiliki keterampilan tinggi biasanya mendominasi pada kondisi tertentu, seorang pemain sepakbola harus saling bergantung pada setiap anggota tim untuk menciptakan permainan cantik dan membuat keputusan tepat. Tim sepakbola terdiri dari sepuluh pemain lapangan dan satu penjaga gawang. Keterampilan untuk mengoper dan menerima bola membentuk jalinan vital yang menghubungkan kesebelas pemain ke dalam satu unit yang berfungsi lebih baik dari pada bagianbagiannya. Ketepatan, langkah, dan waktu pelepasan bola merupakan bagian yang penting dari kombinasi pengoperan bola yang berhasil. Keterampilan mengoper dan menerima bola yang tidak baik akan mengakibatkan lepasnya bola dan membuang-buang kesempatan untuk menciptakan gol, adapun teknik dasar dalam permainan sepakbola.

model pembelajaran sebagai satu rencana atau kerangka yang digunakan dalam proses pembelajaran hendaknya memberikan kesempatan untuk terjadinya interaksi aktif antara individu dengan data dan proses berfikir. Dengan penerapan model pembelajaran yang tepat, maka akan tercipta kondisi belajar yang kondusif, efektif, dan efisien serta hasil belajar yang maksimal. Salah satunya model pembelajaran Inquiry.

Model pembelajaran inquiry diciptakan oleh suchman (1962) dengan alasan ingin memberikan perhatian dalam membantu siswa menyelidiki secara independen, namun dalam suatu cara teratur (Trisna, 2016: 203).

Gulo (dalam trianto, 2007: 135) menyatakan model pembelajaran inquiry berarti suatu rancangan kegiatan belajar yang melibatkan secara maksimal seluruh kemampuan siswa untuk mencari dan menyelidiki secara sistematis, kritis, logis, analistis, sehingga mereka dapat merumuskan semua penemuannya dengan percaya diri.

Pembelajaran Inquiry adalah kegiatan pembelajaran yang menenkankan pada proses berfikir secara kritis dan analisis untuk mencari dan menemukan sendiri jawaban dari suatu masalah yang di pertanyakan. Proses berfikir itu sendiri biasa nya dilakukan melalui tanya jawab antara guru dan siswa (Sanjaya, 2016: 196).

Dari beberapa pendapat yang dikemukakan diatas tentang teori bahwa model pembelajaran inquiry adalah model pembelajaran yang menekankan pada proses berfikir untuk menemukan jawaban atas semua pertanyaan berdasarkan landasan teori yang sudah ada dan menarik kesimpulan. 


\section{METODE PENELITIAN}

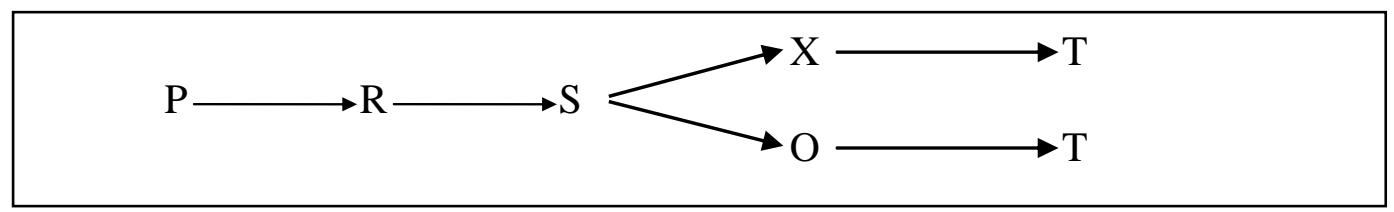

Gambar 0.1.

Rancangan Penelitian (Kanca, 2010:87)

Keterangan:

$\mathrm{P} \quad=$ Populasi

$\mathrm{R} \quad=$ Random

$\mathrm{S} \quad=$ Sampel

T2 = Tes Akhir (posttest)

$\mathrm{X}=$ Kelompok Eksperimen menggunakan model pembelajaran Inquiry

$\mathrm{O}=$ Kelompok Kontrol menggunakan konvensional dengan metode ceramah

$\mathrm{T} \quad=$ Tes Akhir (posttest)

Sampel pada Penelitian ini menggunakan kluster sampling (cluster sampling) adalah penarikan sampel yang didasarkan pada kelompok-kelompok sebagai anggota populasi.

Sampel penelitian di tentukan dengan cara pengambilan sampel berupa kelompok secara sederhana (cluster simple random) yaitu dengan randomisasi kelompok. Asumsi yang dianut pada teknik ini, bahwa masing- masing kelompok adalah relatif homogen dan random dilakukan pada kelompok. sehingga terpilih 2 kelas yaitu kelas VII C dan VII D sebagai sempel penelitian. Jumah siswa sebagai berikut kelas VII C berjumlah 30 orang dan VII D berjumlah 30 orang, sehingga keseluruhan jumlah sampel penelitian adalah 60 orang.

Teknik pengumpulan data menggunakan aspek keterampilan /Skill melalui tes unjuk kerja siswa melakukan passing dan control sepakbola menggunakan kaki bagian dalam. Analisis data penelitian ini menggunakan uji prasyarat yaitu uji normalitas (kolmo) dan homogenitas (levene) dan uji hipotesis menggunakan uji-t. Analisis data pada penelitian ini secara keseluruhan dikerjakan dengan aplikasi program Statistical product and service solutions (SPSS) 16.0 for Windows. 


\section{HASIL DAN PEMBAHASAN}

Data hasil belajar keterampilan/ Skill passing dan control sepakbola menggunakan kaki bagian dalam diperoleh melalui tes untuk kelompok

eksperimen dan kelompok kontrol. Data yang dianalisis adalah tes Akhir (posttest).

Tabel 1

Rangkuman Data Hasil Belajar Passing Dan Control Sepakbola

Descriptive Statistics

\begin{tabular}{|c|c|c|c|}
\hline Variabel & Banyak Siswa & Rata- rata & Std. Deviation \\
\hline Kelas kelompok eksperimen & 30 & 77.00 & 14,36 \\
\hline Kelas kelompok kontrol & 30 & 60.00 & 16,50 \\
\hline $\begin{array}{l}\text { Berdasarkan tabel } \\
\text { hasil data dari kedua } \\
\text { eksperimen dan kelomp } \\
\text { diperoleh rata-rata skor da } \\
\text { eksperimen }=77,00 \text { sedar }\end{array}$ & $\begin{array}{l}\text { entang } \\
\text { ompok } \\
\text { rontrol, } \\
\text { ompok } \\
\text { n rata- }\end{array}$ & \multicolumn{2}{|c|}{$\begin{array}{l}\text { rata skor dari kelompok kontrol= } \\
60,00 \text {. Standar deviasi kelompok } \\
\text { eksperimen }=14,36 \text { sedangkan } \\
\text { standar deviasi kelompok kontrol= } \\
16,50 \text {. }\end{array}$} \\
\hline
\end{tabular}

Tabel 02

Hasil Uji Normalitas Sebaran Data

\begin{tabular}{lllllllll}
\hline & & \multicolumn{3}{c}{ Kolmogorov-Smirnov ${ }^{\mathrm{a}}$} & \multicolumn{3}{c}{ Shapiro-Wilk } \\
\cline { 3 - 9 } & kelompok & Statistic & $\mathrm{df}$ & \multicolumn{1}{c}{ Sig. } & Statistic & $\mathrm{df}$ & Sig. \\
\hline hasil & eksperime & .117 & 30 & $.200^{*}$ & .938 & 30 & .079 \\
belajar & $\mathrm{n}$ & & & & & & \\
\cline { 2 - 9 } & kontrol & .128 & 30 & $.200^{*}$ & .946 & 30 & .133 \\
\hline
\end{tabular}

Uji normalitas yang digunakan adalah Uji Kolmogorov-Smirnov. Jika nilai sig pada kolom KolmogorovSmirnov untuk kedua kelas lebih dari 0.05 maka data kedua kelas berasal dari populasi yang berdistribusi normal. Nilai sig untuk kelas VIIC dan kelas VIID adalah 0.200 dan 0.200 yaitu lebih dari 0.05 sehingga data kedua kelas berasal dari populasi yang berdistribusi normal.

Tabel 03

Rangkuman Hasil Uji Homogenitas Varians menggunakan Levene's Test of Equality of Error Variances ${ }^{a}$

\begin{tabular}{llrrrr}
\hline & \multicolumn{2}{c}{$\begin{array}{c}\text { Levene } \\
\text { Statistic }\end{array}$} & df1 & df2 & \multicolumn{1}{c}{ Sig. } \\
\hline hasil & Based on Mean & .703 & 1 & 58 & .405 \\
\cline { 2 - 7 } belajar & Based on Median & .665 & 1 & 58 & .418 \\
\cline { 2 - 6 } & $\begin{array}{l}\text { Based on Median } \\
\text { and with adjusted df }\end{array}$ & .665 & 1 & 55.422 & .418 \\
& & & & & \\
\hline
\end{tabular}




\begin{tabular}{|c|c|c|c|c|c|}
\hline & & $\begin{array}{l}\text { Levene } \\
\text { Statistic }\end{array}$ & df1 & $\mathrm{df2}$ & Sig. \\
\hline \multirow{4}{*}{$\begin{array}{l}\text { hasil } \\
\text { belajar }\end{array}$} & Based on Mean & .703 & 1 & 58 & .405 \\
\hline & Based on Median & .665 & 1 & 58 & .418 \\
\hline & $\begin{array}{l}\text { Based on Median } \\
\text { and with adjusted df }\end{array}$ & .665 & 1 & 55.422 & .418 \\
\hline & $\begin{array}{l}\text { Based on trimmed } \\
\text { mean }\end{array}$ & .703 & 1 & 58 & .405 \\
\hline
\end{tabular}

Berdasarkan Tabel 4.3, hasil uji Levene's Test of Equality of Error Variances menunjukkan bahwa untuk hasil belajar passing dan control sepakbola siswa taraf signifikansi 0,405. Bila ditetapkan taraf signifikansi 0,05 maka nilai sig. lebih besar dari taraf signifikansi yang ditetapkan. Dengan demikian hipotesis nol diterima. Artinya, semua kelompok data memiliki varians yang sama (homogen).

Tabel 04

Hasil Uji-t dengan Menggunakan Independent Samples Test Levene's Test for Equality of Variances t-test for Equality of Means

\begin{tabular}{|c|c|c|c|c|c|c|c|c|c|c|}
\hline & & & & & & & & & \multicolumn{2}{|c|}{$\begin{array}{l}95 \% \text { Confidence } \\
\text { Interval of the } \\
\text { Difference }\end{array}$} \\
\hline & & $\mathrm{F}$ & Sig. & $t$ & df & $\begin{array}{l}\text { Sig. (2- } \\
\text { tailed) }\end{array}$ & $\begin{array}{l}\text { Mean } \\
\text { Differen } \\
\text { ce }\end{array}$ & $\begin{array}{l}\text { Std. } \\
\text { Error } \\
\text { Differen } \\
\text { ce }\end{array}$ & Lower & Upper \\
\hline \multirow[t]{2}{*}{$\begin{array}{l}\text { hasil } \\
\text { belajar }\end{array}$} & $\begin{array}{l}\text { Equal } \\
\text { variances } \\
\text { assumed }\end{array}$ & .703 & .405 & $\begin{array}{r}4.25 \\
6\end{array}$ & 58 & .000 & 17.000 & 3.994 & 9.005 & 24.995 \\
\hline & $\begin{array}{l}\text { Equal } \\
\text { variances } \\
\text { not assumed }\end{array}$ & & & $\begin{array}{r}4.25 \\
6\end{array}$ & $\begin{array}{r}56.9 \\
11\end{array}$ & .000 & 17.000 & 3.994 & 9.001 & 24.999 \\
\hline
\end{tabular}

Berdasarkan Tabel 4.4 Pada kolom sig (2-tailed) jika nilai sig $<0.05$ artinya $\mathrm{H}_{\mathrm{o}}$ ditolak dan $\mathrm{H}_{\mathrm{a}}$ diterima. Nilai sig untuk uji hipotesis adalah $0.000<0.05(\mathrm{P}<0.05)$ sehingga $\mathrm{H}_{0}$ ditolak dan $\mathrm{H}_{\mathrm{a}}$ diterima. Hasil ini

\section{E. SIMPULAN DAN SARAN}

Hasil penelitian yang dilakukan di SMP N 3 Sukasada pada siswa kelas eksperimen tentang pengaruh model pembelajaran inquiry khususnya mata pelajaran PJOK pada materi passing dan control sepakbola menggunakan kaki bagian dalam, pembelajaran dengan menyatakan bahwa terdapat perbedaan hasil belajar passing dan control sepakbola. Sehingga model pembelajaran Inquiry berpengaruh signifikan terhadap hasil belajar passing dan control sepakbola pada siswa kelas VII SMP N 3 Sukasada. menggunakan model inquiry memberikan pengaruh yang signifikan terhadap kemampuan berfikir kritis siswa berkemampuan tinggi, sedang dan rendah. ini bisa di lihat dari hasil dimana standar deviasi kelompok eksperimen lebih rendah dari kelompok kontrol, bisa dinyatakan rendah karena daya serap siswa 
terhadap materi yang dipelajari sangat merata dan bisa dikatakan Homogen.

$$
\text { Menggunakan model }
$$

pembelajaran Inquiry membuat sikap siswa lebih aktif dalam pembelajaran, baik dalam kelompok maupun perorangan karena setiap siswa disibukkan dengan materi yang akan dipelajari dan waktu yang diberikan sesuai dengan sintak/urutan dalam proses pembelajaran.

Siswa memberikan respon yang baik terhadap penggunaan model Inquiry pada pembelajaran PJOK terutama pada materi Passing dan Control Sepakbola menggunakan kaki bagian dalam dikarenakan siswa senang dengan materi sepakbola, maka dari itu sebagai Guru harus bisa membuat pembelajaran MUKIDI (Menyenangkan, Unik, Kreatif, Inovatif, Denotatif, Inspiratif).

\section{DAFTAR PUSTAKA}

Jampel, Nyoman. 2016. Pedoman Penulisan Karya IImiah Tugas Akhir, Skripsi, Tesis, dan Disertasi. Singaraja: Undiksha.

Sugiyono. 2018. Metode Penelitian Manajement. Bandung: Alfabeta.

Kanca, I Nyoman. 2010. Metode Penelitian pengajaran Pendidikan Jasmani dan Olahraga. Singaraja: Undiksha.

Dantes, Nyoman. 2012. Metode Penelitian. Yogyakarta: Andi.

Artanayasa, I Wayan. 2016. Pengaruh Model Pembelajaran dan Penilaian Autentik Terhadap Hasil Belajar Keterampilan Sepakbola dengan Mengontrol Motor Educatibility. Jakarta: Universitas Negeri Jakarta.

Sagala, Syaiful. 2014. Konsep dan Makna Pembelajaran untuk membantu memecahkan Problematika belajar dan mengajar. Bandung: Alfabeta.
Trisna, Ega. 2016. Strategi Pembelajaran Pendidikan Jasmani. Bandung: Alfabeta.

Trianto. $2007 . \quad M o d e l-m o d e l$ Pembelajaran Inovatif Berorientasi Konstruktivistik. Jakarta: Prestasi Pustaka Publisher.

Dimiyati dan Mudjiono. 2013. Belajar dan Pembelajaran. Jakarta: Rineka Cipta.

Sanjaya, Wina. 2016. Strategi Pembelajaran Berorientasi Standard Proses Pendidikan. Jakarta: Kencana Prenada Media Group.

Satyawan, I Made. 2012. Buku Ajar Permainan Sepakbola. Singaraja: Universitas Pendidikan Ganesha.

Mielke, Danny. 2007. Dasar-dasar Sepakbola. Bandung: Pakar Raya.

Depdiknas. 2018. Peraturan Menteri Pendidikan dan Kebudayaan Republik Indonesia Nomor 160 Tahun 2014 tentang Pemberlakuan Kurikulum Tahun 2006 dan Kurikulum 2013.Pemendikbud. 2018. Materi Penyegaran Intruktur Kurikulum 2013 Sekolah Menengah pertama. 